\title{
Decreased expression of retinoid nuclear receptor (RAR $\alpha$ and RAR $\gamma$ ) mRNA determined by real-time quantitative RT-PCR in peripheral blood mononuclear cells of hypothyroid patients
}

\author{
C Féart ${ }^{1}$, J Vallortigara ${ }^{1}$, D Higueret ${ }^{2}$, B Gatta ${ }^{3}$, A Tabarin ${ }^{3}$, V Enderlin ${ }^{1}$, P Higueret ${ }^{1}$ and \\ V Pallet ${ }^{1}$ \\ ${ }^{1}$ Unité de Nutrition et Signalisation Cellulaire (E.A. MENRT, Usc INRA) ISTAB, Avenue des Facultés Université Bordeaux 1, 33405 Talence, France \\ ${ }^{2}$ Service de Biochimie de l'Hôpital Pellegrin, Centre Hospitalier Universitaire de Bordeaux, Place Amélie Raba Léon, 33000 Bordeaux, France \\ ${ }^{3}$ Service d'Endocrinologie, Diabétologie et Maladies Métaboliques de l'Hôpital Haut-Levêque, Centre Hospitalier Universitaire de Bordeaux, Avenue Magellan, 33600 Pessac, \\ France
}

(Requests for offprints should be addressed to V Pallet; Email: v.pallet@istab.u-bordeaux1.fr)

\begin{abstract}
In vivo assessment of the cellular impact of thyroid hormones on target tissues might be of help for physiological studies and to evaluate the consequences of various diseases of the thyroid gland in humans. Given the tenuous relationship between retinoid and tri-iodothyronine $\left(T_{3}\right)$ status and that retinoids have also intracellular roles, the aim of this study was to determine the effect of hypothyroidism on the expression of $T_{3}$ nuclear receptors (TR) and retinoic acid nuclear receptors (RAR, RXR) in human peripheral blood mononuclear cells (PBMC). Using real time RT-PCR, we quantified the relative amount of mRNA of the thyroid (TR $\alpha$ and $\operatorname{TR} \beta$ ) and retinoid (RAR $\alpha$, RAR $\gamma$, and $\operatorname{RXR} \alpha$ ) nuclear receptors in PBMC of euthyroid $(n=22)$ compared with hypothyroid $(n=22)$ subjects. Classical plasma parameters (free $\mathrm{T}_{3}\left(\mathrm{FT}_{3}\right)$, free thyroxine $\left(\mathrm{T}_{4}\right)\left(\mathrm{FT}_{4}\right)$, thyroid-stimulating hormone $(\mathrm{TSH})$, retinol $(\mathrm{ROH})$, retinol-binding protein (RBP) and transthyretin (TTR)) were also measured. In hypothyroid subjects, the concentration of TSH was elevated, and dramatically low $T_{3}$ and $T_{4}$ concentrations were associated with a decrease in the expression of TR $\beta$. Expression of RAR $\alpha$ and RAR $\gamma$ significantly decreased in hypothyroid versus control subjects, while an increased concentration of $\mathrm{ROH}$ was emphasised by hypothyroidism. These results first indicated that primary hypothyroidism induces hypoactivation of the retinoid nuclear pathway in PBMC, which was not predicted by the plasma ROH level. Further investigations will be necessary to evaluate these parameters in very small changes in thyroid hormone production such as mild (subclinical) hypothyroidism.
\end{abstract}

Journal of Molecular Endocrinology (2005) 34, 849-858

\section{Introduction}

The physiological actions of thyroid hormones in the regulation of diverse cellular activities, including normal growth and general metabolism, are well defined (reviewed by Yen 2001). Thyroid disorders such as hyper- and hypothyroidism induce considerable consequences in children and adults. For example, children born with congenital hypothyroidism who lack thyroid hormones during a circumscribed period of early development are at risk of brain damage and mental retardation (reviewed by Rovet \& Daneman 2003). Assessment of thyroid function in humans is commonly performed with plasma free thyroxine $\left(\mathrm{T}_{4}\right)$ and thyroid-stimulating hormone (TSH) measurements. Low serum free $(\mathrm{F}) \mathrm{T}_{4}$ contrasting with elevated $\mathrm{TSH}$ concentrations confirms the diagnosis of hypothyroidism and signifies that it is due to failure of the thyroid gland (primary hypothyroidism). Thus, in human studies, only plasma parameters are used to characterise the thyroid hormone status of an individual even though thyroid hormones have a mainly intracellular role. Indeed, there is strong evidence pointing to the nucleus as the principal site for the initiation of thyroid hormone action (Oppenheimer 1999). Assessment of the cellular impact of thyroid hormone deficiency might be of help in circumstances such as thyroid hormone resistance. Elsewhere, many older patient have abnormal TSH levels without other alterations in serum thyroid hormone levels, a condition defined as subclinical hypothyroidism that occurs in $4 \cdot 5-8 \%$ of elderly subjects (Surks et al. 2004). The clinical consequences of this condition are controversial; therefore, there is need for the development of alternative markers of the cellular 
impact of thyroid hormones. Within the cell, these actions are mediated by specific tri-iodothyronine $\left(\mathrm{T}_{3}\right)$ nuclear receptors $(\mathrm{TR} \alpha$ and $\operatorname{TR} \beta)$, which regulate the expression of targeted genes (reviewed by Yen 2001, Viguerie \& Langin 2003). These receptors belong to the superfamily of hormone nuclear receptors, which function as ligand-activated transcription factors (Aranda \& Pascual 2001).

Like TR, retinoid nuclear receptors (RAR $\alpha,-\beta$ and $-\gamma$ and $\operatorname{RXR} \alpha,-\beta$ and $-\gamma$ ) are members of the hormone receptor superfamily and regulate target genes in response to RA (retinoic acid) ligand (RA is the active form of vitamin A) (Marill et al. 2003). Vitamin A, via RA, exerts a wide variety of profound effects on growth, tissue differentiation and homeostasis (Sporn et al. 1994, reviewed by Bastien \& Rochette-Egly 2004). It has been shown that RXR forms heterodimers with either RAR or TR in order to regulate gene transcription by interacting with distinct sequences in the promoter of target genes. The fact that RXR is the essential common partner for the functional heterodimer indicates that thyroid hormones and retinoid signalling pathways are closely related (Schräder \& Carlberg 1994, Mangelsdorf \& Evans 1995, Li et al. 2002). We have shown that a decrease in maximal binding capacity of TR and RAR in the liver, as well as decreased affinity for their ligand, has been observed in hypothyroid rats compared with controls (Pallet et al. 1994). Inversely, vitamin A status may influence thyroid hormone signalling. Indeed, decreased expression of TR has been observed in the liver and the brain of rats fed a vitamin A-deficient diet (Higueret et al. 1989, Husson et al. 2003). Likewise, many interactions between thyroid hormones and retinoid nuclear signalling have been reported, at the plasmatic level, in studies performed in humans or animals. Hypothyroidism is associated with elevated retinol $(\mathrm{ROH})$ and $\beta$-carotene concentrations in humans (Goswami \& Choudhury 1999). Mice lacking the transthyretin gene (TTR), a protein that binds and carries thyroxin, exhibit decreased $\mathrm{ROH}$ and retinolbinding protein (RBP) concentrations (van Bennekum et al. 2001). Moreover, Coya et al. (1997) have reported that TSH secretion in rats is partly regulated in vivo by RA.

Expression of TR $\alpha$ and TR $\beta$ in peripheral blood mononuclear cells (PBMC) is sensitive to thyroid status (Meier-Heusler et al. 1995). The RA nuclear receptors $\operatorname{RAR} \alpha, \operatorname{RAR} \gamma, \operatorname{RXR} \alpha$ and $\operatorname{RXR} \beta$ have also been found in these cells (Szabova et al. 2003). Given that retinoids and thyroid hormones have mainly intracellular action, the aim of the present study was twofold: firstly, to establish the effect of primary hypothyroidism on the expression of $\mathrm{TR} \alpha$ and $\mathrm{TR} \beta$ in human PBMC; secondly, to clarify the effect on the expression of the retinoid nuclear receptors $\operatorname{RAR} \alpha, \operatorname{RAR} \gamma$ and $\operatorname{RXR} \alpha$ in PBMC. The amount of mRNA of TR $\alpha, \operatorname{TR} \beta, \operatorname{RAR} \alpha$,
$\operatorname{RAR} \gamma$ and $\operatorname{RXR} \alpha$ was quantified by the real-time RT-PCR method.

The classical thyroid parameters of euthyroid and hypothyroid subjects were also measured $\left(\mathrm{FT}_{3}, \mathrm{FT}_{4}\right.$ and TSH), as well as those classically used to qualify the vitamin A status $(\mathrm{ROH}$ and $\mathrm{RBP}$ concentrations and the RBP:TTR ratio assessment).

\section{Materials and methods}

\section{Subjects}

Forty-four men and women volunteers are recruited for this study: 22 (24-57 years old) in the euthyroid group and 22 (24-67 years old) in the hypothyroid group. Subjects of the euthyroid group were selected from volunteers, according to their health (and thyroid status). Hypothyroid patients were recruited in the Endocrinology, Diabetology, and Metabolic Disease Unit of l'Hôpital Haut-Levêque, a university teaching hospital in Bordeaux, France. All patients underwent total thyroidectomy for papillary carcinoma and were referred for complementary ${ }^{131} \mathrm{I}$ therapy. For this purpose, thyroid hormone replacement therapy was withdrawn for 4 weeks, and all patients were on a mild low-iodine diet during these 4 weeks. Blood samples were collected immediately prior to radioactive iodine therapy. All patients gave informed consent.

\section{Health status}

Venous blood was collected from all subjects after overnight fasting ( $\approx 12 \mathrm{~h}$ after previous meal). Diagnostics kits (RIA and IRMA; Immunotech, Marseille, France) were used to measure plasma $\mathrm{FT}_{3}(n=22$ in euthyroid group), $\mathrm{FT}_{4}(n=22$ in euthyroid group) and TSH $(n=20$ and $n=22$ in euthyroid and hypothyroid groups respectively) concentration. The plasma ROH $(n=20$ and $n=22$ in euthyroid and hypothyroid groups respectively) concentration was determined by HPLC by the method of Leclercq and Bourgeay-Causse (1981). Plasma TTR $(n=19$ and $n=22$ in euthyroid and hypothyroid groups respectively) and $\operatorname{RBP}(n=19$ and $n=22$ in euthyroid and hypothyroid groups respectively) concentrations were measured by the immunonephelometric process (Nephelometer Analyser II; Behring Diagnostics, Deerfield, IL, USA). Total plasma cholesterol (TC) $n=21$ and $n=22$ in euthyroid and hypothyroid groups respectively) and total triglyceride (TTG) $(n=21$ and $n=22$ in euthyroid and hypothyroid groups respectively) concentrations were measured by the enzymatic method with a Synchron CX5 analyser (Beckman Coulter, Villepinte, France).

\section{Preparation of PBMC}

PBMC were isolated by density gradient centrifugation with Ficoll-Paque Plus solution (Amersham Biosciences, 
Table 1 Primers used for LightCycler real-time PCR

\begin{tabular}{|c|c|c|c|c|}
\hline & Ref & $\begin{array}{l}\text { Sequence } \\
\text { Sequences are shown for forward }(F) \text { and } \\
\text { reverse }(R) \text { primers as well as size of amplicon }\end{array}$ & Position & $\begin{array}{l}\text { Product } \\
\text { length } \\
\text { (bp) }\end{array}$ \\
\hline \multicolumn{5}{|l|}{ PCR primer pair } \\
\hline PBGD & Raich et al. 1986 & $\begin{array}{l}\text { F: 5'-TGCACGATCCCGAGACTCTGC-3' } \\
\text { R: 5'-GCACGGCTACTGGCACACTGC-3' }\end{array}$ & $\begin{array}{l}743-763 \\
812-832\end{array}$ & 90 \\
\hline Cyclophilin & Haendler et al. 1987 & $\begin{array}{l}\text { F: 5'-TCCTAAAGCATACGGGTCCTGGCAT-3' } \\
\text { R: 5'-CGCTCCATGGCCTCCACAATATTCA-3' }\end{array}$ & $\begin{array}{l}280-304 \\
421-445\end{array}$ & 165 \\
\hline $\mathrm{RAR} \alpha$ & Giguere et al. 1987 & $\begin{array}{l}\text { F: 5'-CTGCCAGTACTGCCGACTGC-3' } \\
\text { R: 5'-ACGTTGTTCTGAGCTGTTGTTCGTA-3' }\end{array}$ & $\begin{array}{l}519-538 \\
729-753\end{array}$ & 235 \\
\hline $\mathrm{RAR} \gamma$ & Krust et al. 1989 & $\begin{array}{l}\text { F: 5'-CTGCCAGTACTGCCGGCTAC-3' } \\
\text { R: 5'-TCTGCACTGGAGTTCGTGGTATACT-3' }\end{array}$ & $\begin{array}{l}837-856 \\
1040-1064\end{array}$ & 228 \\
\hline $\mathrm{RXR} \alpha$ & Mangelsdorf et al. 1990 & $\begin{array}{l}\text { F: 5'-CGACCCTGTCACCAACATTTGC-3' } \\
\text { R: 5'-GAGCAGCTCATTCCAGCCTGCC-3' }\end{array}$ & $\begin{array}{l}861-882 \\
981-1002\end{array}$ & 142 \\
\hline $\operatorname{TR} \alpha$ & Laudet et al. 1991 & $\begin{array}{l}\text { F: 5'-GTTCTAGATGACTCGAAGGCGGG-3' } \\
\text { R: 5'-CTTCAGGAGTGGGCTCTGGTCG-3' }\end{array}$ & $\begin{array}{l}838-860 \\
935-956\end{array}$ & 119 \\
\hline TR $\beta$ & Weinberger et al. 1986 & $\begin{array}{l}\text { F: 5'-CCGAAGCACTGTCCAGACCGAGAAC-3' } \\
\text { R: 5'-TCAAAGACTTCCAAGAAGAGAGGC-3' }\end{array}$ & $\begin{array}{l}334-358 \\
399-423\end{array}$ & 90 \\
\hline
\end{tabular}

F-91898 Orsay Cedex, France). After overnight fasting, venous blood $(5 \mathrm{ml})$ was drawn into an EDTA-coated vacutainer tube, layered onto $4 \mathrm{ml}$ Ficoll-Paque Plus solution and then centrifuged at $400 \mathrm{~g}$ for $20 \mathrm{~min}$ at $20{ }^{\circ} \mathrm{C}$. PBMC were removed from the plasma-Ficoll interface and washed twice in $1 \mathrm{M} \mathrm{PBS}, \mathrm{pH} 7 \cdot 2$, to remove platelets, Ficoll-Paque and plasma. PBMC were then suspended in TRIzol Reagent (Invitrogen, CergyPontoise, France) for total RNA preparation. PBMC from euthyroid and hypothyroid subjects were assayed simultaneously in all assays to ensure that differences between groups were indeed biological, and not a result of interassay variation.

\section{Quantification of mRNA expression}

\section{Total RNA preparation}

PBMC were directly homogenised in $1 \mathrm{ml}$ TRIzol reagent solution, and total RNA was extracted by the manufacturer's suggested protocol for small quantities of tissue. Purified RNA was quantified and assessed for purity by UV spectrophotometry. Average yield of total RNA extraction was not significantly different in PBMC from euthyroid and hypothyroid subjects.

\section{Reverse transcription and analysis of gene expression}

An amount of $1 \mu \mathrm{g}$ total RNA, mixed with RNasin (40 U, Promega, Charbonniére, France) and with DNase (20 U, Roche Diagnostics, Meylan, France) was incubated for $15 \mathrm{~min}$ at $37^{\circ} \mathrm{C}$ in order to denaturate DNA and inhibit RNase. Then, reverse primers were added for incubation for $10 \mathrm{~min}$ at $70{ }^{\circ} \mathrm{C}$. Next, the solution was mixed with 5 First Strand Buffer
(Invitrogen), DTT (0.1 M, Invitrogen), dNTP (10 mM each one) and Superscript II reverse transcriptase (Invitrogen) for $1 \mathrm{~h}$ at $42{ }^{\circ} \mathrm{C}$.

Real-time PCR assay involving LightCycler technology associates rapid thermocycling with on-line fluorescence detection of the PCR products. PGR reactions were performed in a volume of $20 \mu \mathrm{l}$ containing oligonucleotide primers $(5 \mu \mathrm{M}$ of each), $\mathrm{MgCl}_{2}$ (5 mM) and DNA Master SYBR green (Roche) containing Taq DNA polymerase, reaction buffer, dNTP and the double-stranded DNA-specific fluorescent dye, SYBR green I. Amplification occurred in a two-step procedure: denaturation at $95^{\circ} \mathrm{C}$ for $10 \mathrm{~min}$ and 30 cycles with denaturation at $95^{\circ} \mathrm{C}$ for $8 \mathrm{~s}$, annealing at $66^{\circ} \mathrm{C}$ for $6 \mathrm{~s}$ and extension at $72{ }^{\circ} \mathrm{C}$ for 10 s. Acquisition of the fluorescent signal from the samples was carried out at the end of elongation step. The forward and reverse primer sequences are shown in Table 1. Specificity of primers was validated through the verification of RT-PCR product specificity. The identity of amplified products was verified by sequencing with the Dye Terminator Reaction Cycle Kit (Perkin-Elmer, Norwalk, CT, USA) and analysed on an ABI PRISM 377 automated DNA sequencer (Perkin-Elmer).

Quantification data were analysed by LightCycler analysis software, Version 3.5 (Roche). In this analysis, the background fluorescence was removed by setting a noise band. The log-linear portion of the standard amplification curve was identified, and the crossing point (Cp) was the intersection of the best-fit line through the log-linear region and the noise band. The standard curve was a plot of the $\mathrm{Cp}$ versus the amount of the initial cDNA used for amplification. The Cp was always 
(A)

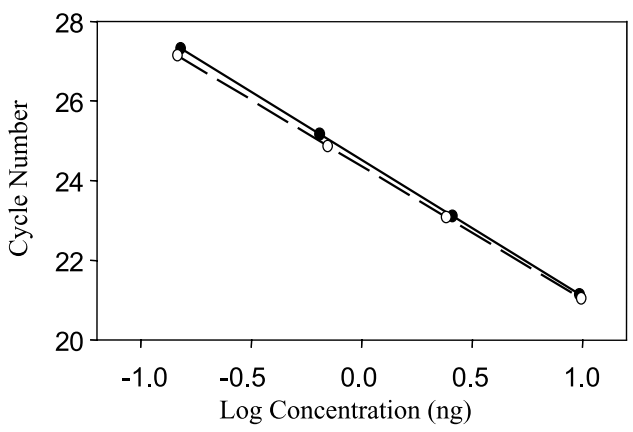

(B)

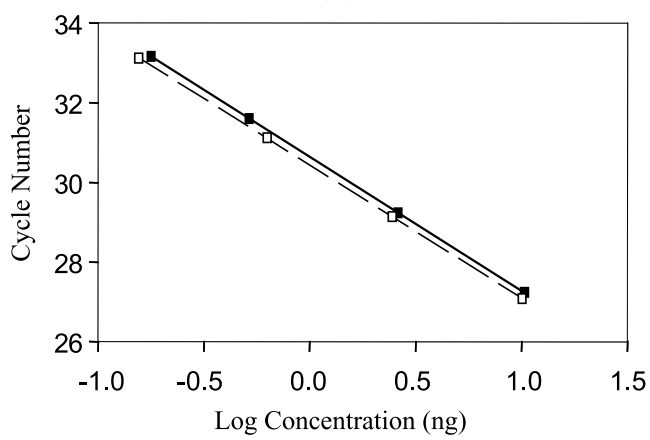

(C)

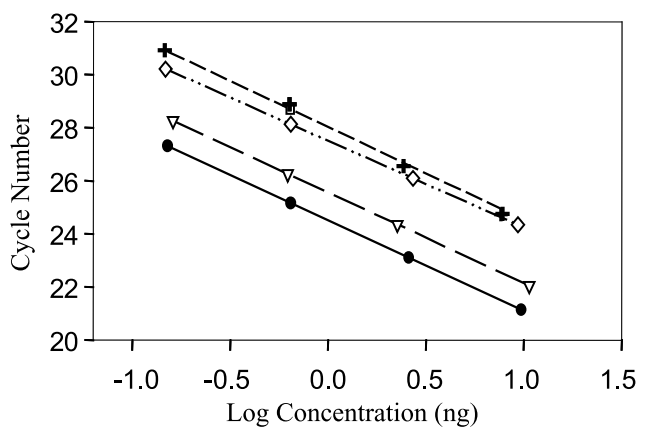

(D)

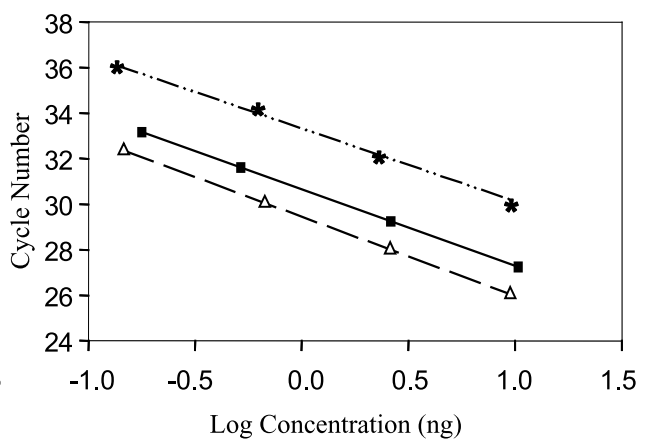

Figure 1 Standard curves for housekeeping genes: (A) cyclophilin, $\bullet$ in euthyroid group and $\bigcirc$ in hypothyroid group; (B) porphobilinogen deaminase (PBGD), $\boldsymbol{\|}$ in euthyroid group and $\square$ in hypothyroid group). Standard curves for target genes in euthyroid group: (C) RXR $\alpha(\diamond), \operatorname{RAR} \alpha$ $(\nabla)$ and TR $\alpha(+)$ relative to cyclophilin $(\bullet)$; (D) RAR $\gamma(\triangle)$ and TR $\beta\left(^{*}\right)$ relative to PBGD $(\square)$.

the same for a given dilution of cyclophilin or porphobilinogen deaminase (PBGD) cDNA, whatever the thyroid status of the subjects, demonstrating that cyclophilin and PBGD mRNA expression were not altered by thyroid status and could be used as normaliser for data from target mRNA (Fig. 1). The relation between the $\mathrm{Cp}$ and the initial amount of cDNA was found to be linear. The correlation coefficient $(r)$ was 1, and PCR amplification efficiencies of the target and the housekeeping genes were similar and close to $100 \%$ (Fig. 1). These standard curves were used to estimate the concentration of both the target and the housekeeping genes in each sample. The results were then normalised by the ratio of the relative concentration of target to that of housekeeping in the same sample.

Cyclophilin cDNA was used as housekeeping for the relative quantification of cDNA of $\operatorname{RAR} \alpha(n=15$ and $n=22$ in euthyroid and hypothyroid groups respectively), $\operatorname{RXR} \alpha(n=12$ and $n=20$ in euthyroid and hypothyroid groups respectively) and $\operatorname{TR} \alpha(n=19$ and $n=20$ in euthyroid and hypothyroid groups respectively), and PBGD was used for the relative quantification of RAR $\gamma$ ( $n=16$ and $n=20$ in euthyroid and hypothyroid groups respectively) and $\operatorname{TR} \beta$ ( $n=14$ and $n=19$ in euthyroid and hypothyroid groups respectively).

\section{Statistical analysis}

Data are expressed as means \pm S.E.M. All statistics were analysed by Statgraphics Plus software. The statistical significance of differences between means was calculated by ANOVA followed by Student's $t$-test, in which equality of S.D. was not assumed because it appeared different between the two groups. Linear regression was used to analyse the relationships between variables. Statistical significance was accepted at $P<0 \cdot 05$.

\section{Results}

\section{Thyroid status and mRNA expression of TR $\alpha$ and TR $\beta$ in PBMC from euthyroid and hypothyroid subjects}

The results are summarised in Tables 2 and 3.

The plasma free thyroid hormone concentrations $\left(\mathrm{FT}_{3}\right.$ and $\left.\mathrm{FT}_{4}\right)$ and the TSH concentration are used clinically to diagnose thyroid disorders. In the hypothyroid group, the $\mathrm{FT}_{3}$ and $\mathrm{FT}_{4}$ concentrations were undetectable, while the TSH concentration was dramatically increased compared with the euthyroid group $(P<0 \cdot 0001)$. 
Table 2 Plasma concentration of thyroid hormones, vitamin A and transport proteins in the euthyroid and hypothyroid groups

\begin{tabular}{|c|c|c|c|c|c|c|}
\hline & & & $\begin{array}{l}\text { Euthyroid g } \\
\text { (total } n=22 \text { ) }\end{array}$ & & $\begin{array}{l}\text { Hypothyroid } \\
\text { (total } n=22 \text { ) }\end{array}$ & \\
\hline & & $\begin{array}{l}\text { Laboratory } \\
\text { reference range }\end{array}$ & Mean \pm S.E.M. & Range & Mean \pm S.E.M. & Range \\
\hline $\mathrm{FT}_{3}$ & $(\mathrm{pmol} / \mathrm{l})$ & $2 \cdot 5-5$ & $\begin{array}{l}3 \cdot 65 \pm 0 \cdot 09 \\
(22)\end{array}$ & $2 \cdot 9-4 \cdot 3$ & ud & - \\
\hline $\mathrm{FT}_{4}$ & $(\mathrm{pmol} / \mathrm{l})$ & $10-20$ & $\begin{array}{l}14 \cdot 07 \pm 0 \cdot 26 \\
(22)\end{array}$ & $11 \cdot 7-16 \cdot 4$ & ud & - \\
\hline TSH & $(\mu \mathrm{Ul} / \mathrm{ml})$ & $0.3-3.5$ & $\begin{array}{l}1 \cdot 77 \pm 0 \cdot 15 \\
(20)\end{array}$ & $0.9-3.8$ & $\begin{array}{l}112 \cdot 3 \pm 15 \cdot 3^{*} \\
(22)\end{array}$ & $10-288$ \\
\hline Retinol & $(\mu \mathrm{mol} / \mathrm{l})$ & $1 \cdot 5-3$ & $\begin{array}{l}2.09 \pm 0.08 \\
(20)\end{array}$ & $1 \cdot 5-2 \cdot 6$ & $\begin{array}{l}2 \cdot 63 \pm 0 \cdot 16^{*} \\
(22)\end{array}$ & $1 \cdot 4-4 \cdot 0$ \\
\hline RBP & $(\mu \mathrm{mol} / \mathrm{l})$ & $1 \cdot 7-2 \cdot 9$ & $\begin{array}{l}2.03 \pm 0.09 \\
(19)\end{array}$ & $1 \cdot 4-2 \cdot 7$ & $\begin{array}{l}2 \cdot 01 \pm 0 \cdot 12 \\
(22)\end{array}$ & $1 \cdot 0-3 \cdot 2$ \\
\hline $\mathrm{ROH}: \mathrm{RBP}$ & $(\mathrm{mol} / \mathrm{mol})$ & $0.9-1.3$ & $\begin{array}{l}1.06 \pm 0.01 \\
(19)\end{array}$ & $0.9-1.2$ & $\begin{array}{l}1 \cdot 31 \pm 0 \cdot 01^{*} \\
(22)\end{array}$ & $1 \cdot 2-1 \cdot 4$ \\
\hline RBP:TTR & $(\mathrm{mol} / \mathrm{mol})$ & - & $\begin{array}{l}0.38 \pm 0.01 \\
(19)\end{array}$ & $0.3-0.5$ & $\begin{array}{l}0.35 \pm 0.01 \\
(22)\end{array}$ & $0.2-0.5$ \\
\hline TTR & $(\mu \mathrm{mol} / \mathrm{l})$ & $3 \cdot 6-7 \cdot 3$ & $\begin{array}{l}5 \cdot 42 \pm 0 \cdot 18 \\
(19)\end{array}$ & $4 \cdot 0-6 \cdot 9$ & $\begin{array}{l}5 \cdot 64 \pm 0 \cdot 18 \\
(22)\end{array}$ & $3 \cdot 1-8 \cdot 5$ \\
\hline Total chole & l (mmol/l) & $4-6 \cdot 2$ & $\begin{array}{l}4 \cdot 96 \pm 0 \cdot 19 \\
(21)\end{array}$ & $3 \cdot 8-7 \cdot 2$ & $\begin{array}{l}8 \cdot 12 \pm 0 \cdot 39^{*} \\
(22)\end{array}$ & $5 \cdot 0-11 \cdot 8$ \\
\hline Total triglyc & $(\mathrm{mmol} / \mathrm{l})$ & $0 \cdot 3-1 \cdot 8$ & $\begin{array}{l}0.77 \pm 0.07 \\
(21)\end{array}$ & $0.3-1 \cdot 3$ & $\begin{array}{l}1.79 \pm 0.18^{*} \\
(22)\end{array}$ & $0.7-3 \cdot 8$ \\
\hline
\end{tabular}

Statistical analyses were performed by ANOVA followed by Student's $t$-test with inequality of S.D.

*Significantly different from euthyroid group, $P<0.05$. ud: undetectable.

The mRNA expression of the thyroid nuclear receptors was assessed in PBMC of healthy euthyroid versus hypothyroid subjects. The amount of TR $\beta$ mRNA was significantly reduced in the hypothyroid compared with the euthyroid group $(-25 \%, P=0 \cdot 016)$. On the other hand, the amount of TR $\alpha$ mRNA remained unchanged $(P=0 \cdot 18)$.

\section{Vitamin A status and mRNA expression of RARa, RAR $\gamma$ and RXR $\alpha$ in PBMC from euthyroid and hypothyroid subjects}

The results are summarised in Tables 2 and 3 .

The vitamin A status of all subjects was determined by measuring $\mathrm{ROH}$ and $\mathrm{RBP}$ concentrations. RBP was proposed as a simple surrogate for vitamin A assessment. Hypothyroid subjects exhibited a significant increase in concentration of $\mathrm{ROH}(+26 \%, P=0.005)$ and no change in RBP concentration. As a consequence, the ratio ROH:RBP also increased in the hypothyroid compared with the euthyroid group $(+24 \%, P<0 \cdot 001)$. The molar ratio RBP:TTR, used as an indirect method of vitamin A assessment, was unchanged in the hypothyroid group compared with the control. TTR, which is both a protein that binds and carries $\mathrm{T}_{4}$ and $\mathrm{a}$ marker of malnutrition, was unaffected by hypothyroidism. Several subtypes of retinoid receptors were expressed in human PBMC. The relative abundance of
RAR $\alpha$ and RAR $\gamma$ mRNA was significantly reduced in PBMC of hypothyroid compared with euthyroid subjects $(-18 \%, \quad P=0 \cdot 016 ; \quad-25 \%, \quad P=0 \cdot 002, \quad$ respectively), whereas the amount of mRNA encoding the RXR $\alpha$ receptor isoform was not modified by hypothyroidism in the PBMC.

\section{Lipid parameters}

The total cholesterol and fasting triglyceride concentrations increased in hypothyroid compared with euthyroid subjects $(+64 \%, P<0 \cdot 01 ;+132 \%, P<0 \cdot 01$, respectively) (Table 2 ).

\section{Correlations between plasma parameters and the relative expression of nuclear receptors}

The results are summarised in Fig. 2.

Correlations were demonstrated between plasma parameters and nuclear receptor mRNA expression. In euthyroid subjects, PBMC TR $\beta$ expression was related to $\mathrm{FT}_{3}$ concentration $(r=0 \cdot 60, P=0 \cdot 022)$. Likewise, a significant positive correlation between the ROH concentration and the mRNA expression of RAR $\gamma$ was found in the euthyroid group $(r=0.52, P=0.045)$ but disappeared in hypothyroid patients $(r=0 \cdot 15$, $P=0 \cdot 53)$. 
Table 3 Effect of hypothyroidism on the relative expression of $\mathrm{T}_{3}$ and retinoic acid nuclear receptors in human PBMC

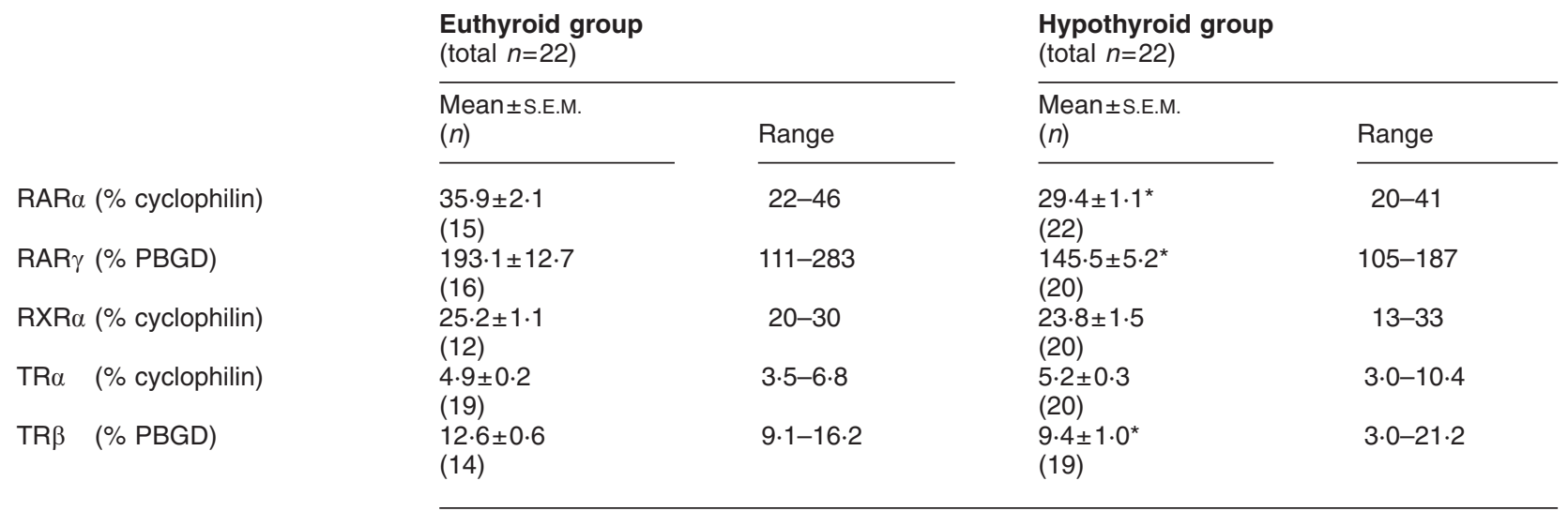

Statistical analyses were performed by ANOVA followed by Student's $t$-test with inequality of S.D.

*Significantly different from euthyroid group, $P<0.05$.

\section{Discussion}

Hypothyroidism, a common thyroid disorder, affects every major organ system and metabolic process (Heitman \& Irizarry 1995). The clinical manifestations of overt hypothyroidism and the effects of this dysfunction on other biological markers, such as lipid status, are well defined at the circulation level in humans. In the present study, total cholesterol and triglycerides were assessed in euthyroid and hypothyroid groups. A classical hypothyroid-related increase in total cholesterol and triglyceride concentrations was described that could be directly attributed to the collapse of the thyroid status because the regulation of the lipid metabolism is $\mathrm{T}_{3}$ dependent (Gullberg et al. 2000, Macchia et al. 2001). Indeed, Efstathiadiou et al. (2001) and Duntas L H (2002) have reported that the composition and transport of lipoproteins are slightly or seriously disturbed in thyroid diseases.

Patients recruited for this study were thyroidectomised for thyroid carcinoma prior to the study, and thyroid hormone replacement therapy was withdrawn for 4 weeks in order to achieve complementary ${ }^{131} \mathrm{I}$ therapy. As expected, patients exhibited a massive rise in TSH concentration with an almost complete disappearance of $\mathrm{T}_{3}$ and $\mathrm{T}_{4}$ from the plasma. These results are consistent with profound although recent hypothyroidism.

The amounts of TR $\alpha$ and TR $\beta$ mRNA were quantified in order to determine the nuclear function of thyroid hormones in the PBMC. Hypothyroidism led to significantly decreased expression of TR $\beta$ mRNA in PBMC, contrary to TR $\alpha$ mRNA expression, which was not significantly changed.

Hormonal regulation of TR in human lymphocytes has been demonstrated, but the present results differ from previous observations. Indeed, $\mathrm{TR} \alpha \mathrm{mRNA}$ has been found to be upregulated by hypothyroidism in lymphocytes (Nagayama et al. 1988). Similarly, Li et al. (1990) have described an increase in the maximal binding capacity of TR in hypothyroid conditions. Meier-Heusler et al. (1995), in developing an assay for the quantitative determination of TR $\beta_{1}$ mRNA levels in human tissue samples, have found no change in TR $\beta$ expression in blood cells from hypothyroid subjects. The present result differed from this last observation, because only a slight but not significantly increased of $\mathrm{TR} \alpha$ mRNA expression was observed. The divergence in $\operatorname{TR} \alpha$ and TR $\beta$ expression between the present results and those of the studies previously mentioned may be due to the sensitivity of the methods used. Indeed, the Northern blot analysis, dot-blot hybridisation and quantitative competitive PCR techniques previously applied are less specific and sensitive than the real-time RT-PCR performed in this study.

In the euthyroid group, the level of expression of TR $\beta$ appeared to be well correlated to the $\mathrm{FT}_{3}$ concentration $(r=0.60, P=0.022)$. In the hypothyroid group, such associations were lost in that $\mathrm{T}_{3}$ disappeared from the circulation.

The effects of hypothyroidism on retinoid nuclear receptors are poorly defined in humans. The circulating levels of the major dietary retinoid detectable in blood, $\mathrm{ROH}$, and its carrier in blood, RBP, have been determined (Almekinder et al. 2000, de Pee \& Dary 2002). This study established that an increase in plasma $\mathrm{ROH}$ level is associated with hypothyroidism. A comparable result has already been obtained in hypothyroid women, who also exhibited an increase in $\beta$-carotene in plasma (Goswami \& Choudhury 1999). The RBP concentration appeared not to be affected by hypothyroidism; indeed, it remained within the laboratory reference range in hypothyroid patients. 

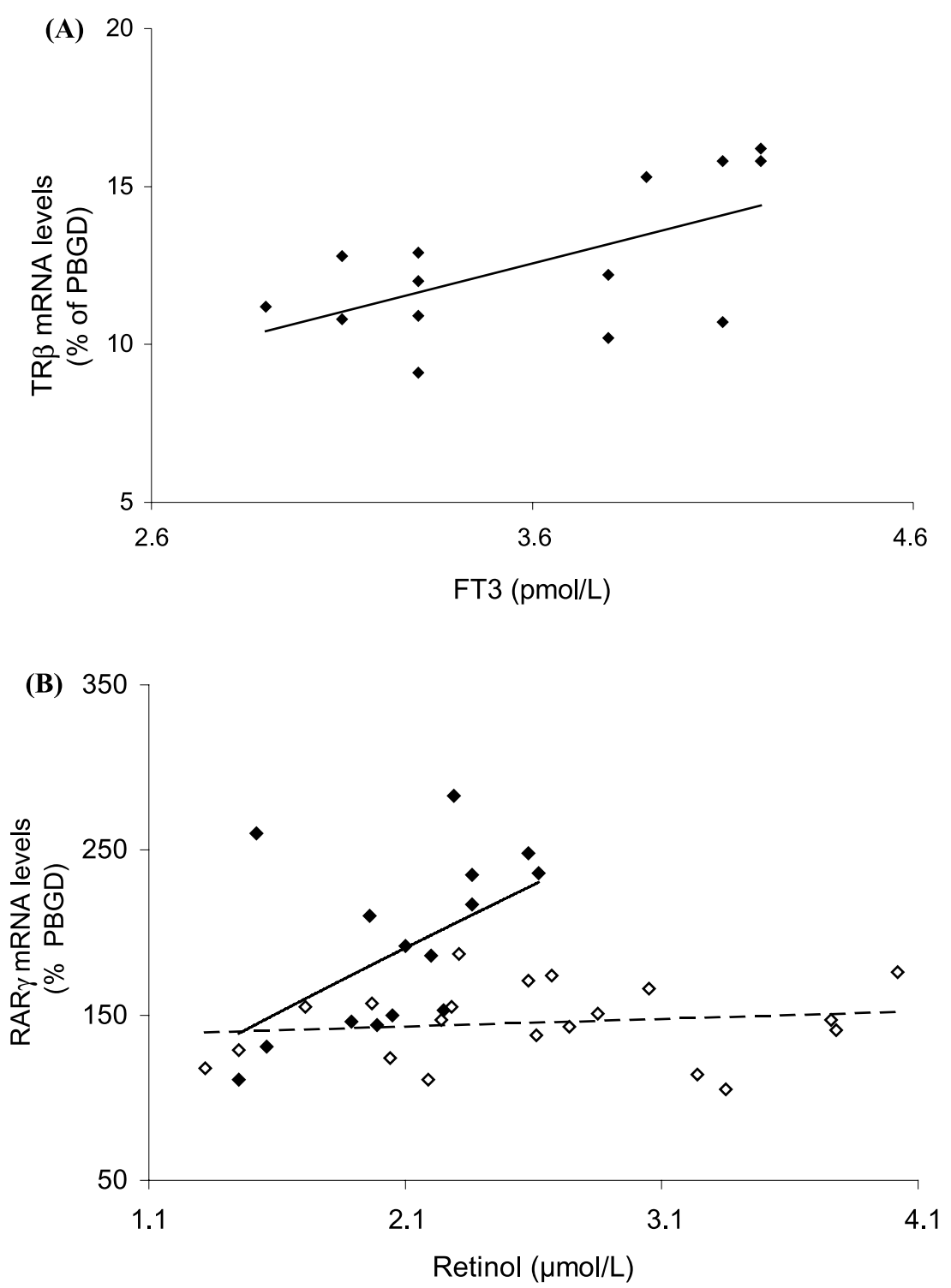

Figure 2 Correlations between (A) TR $\beta$ mRNA levels in PBMC and $\mathrm{FT}_{3}$ concentrations in the euthyroid group ( $: n=14 ; r=0.60, P=0.022)$ and $(B) R A R \gamma$ mRNA levels in PBMC and retinol concentration in the euthyroid $(\wedge: n=15 ; r=0.52, P=0.045)$ and hypothyroid groups $(\diamond: n=20 ; r=0.15, P=0.53)$.

Consequently, the ROH:RBP ratio, which is normally around 1 (revealing the 1:1 molar complex between $\mathrm{ROH}$ and RBP) increased with hypothyroidism. Moreover, it is interesting to note that no subject had a fasting plasma $\mathrm{ROH}$ concentration under $1.4 \mu \mathrm{mol} / \mathrm{l}$, a threshold assumed to indicate a risk of vitamin A deficiency (Hercberg et al. 1994).

TTR plasma concentration is also a sensitive indicator of malnutrition and illness (Robbins 2002). In the present case, hypothyroidism appeared to be without effect on this concentration in plasma. This finding, which has been previously observed by Marrocco et al. (1984), was a further indicator allowing us to say that the population was not affected by malnutrition, particularly lack of iodine. Indeed, a reduction of TTR production rate in combination with its very rapid rate of disappearance from the circulation has been found to occur with malnutrition (Ingenbleek et al. 1975). Moreover, Centanni et al. $(1995,1998)$ found that the RBP and the TTR concentrations decreased in children and adults exposed to mild or overt hypothyroidism due to iodine deficiency. The discrepancy between their 
results and ours could indeed be explained by the fact that, in the present study, recruited subjects were hypothyroid because of thyroidectomy, and not because of deficient iodine intake. The short duration of hypothyroidism in our patients might also play a role. According to the calculation of the RBP:TTR molar ratio, which is presented as an indirect method to evaluate vitamin A status (Rosales et al. 2002, Zago et al. 2002), and which must be above $0 \cdot 37$, euthyroid subjects exhibited good vitamin A status, whereas hypothyroid subjects showed a mean ratio under $0 \cdot 37$, which seemed to indicate a slight risk of vitamin A deficiency (vitamin A deficiency being defined as below 0.37).

The main purpose of the present study was to investigate whether retinoid nuclear signalling, that is, the retinoid nuclear receptors, was modified by hypothyroidism in PBMC, given the close relationship, often described in the literature, between thyroid hormones and retinoid signalling. Indeed, in hypothyroid animals, downregulation of the retinoid nuclear receptors occurs in the liver (Coustaut et al. 1996) and the brain (Enderlin et al. 2004). Thus, the expression of RAR $\alpha, \operatorname{RAR} \gamma$ and RXR $\alpha$ at the mRNA level in the PBMC of euthyroid compared with hypothyroid subjects was quantified. No RXR $\beta$ mRNA was detected in the PBMC of either group. Previously published data are controversial with similar findings to ours (our data were consistent with the observation of Lomo et al. (1998) while Szabova et al. (2003) showed the contrary, that is, the expression of RXR $\beta$ mRNA in human PBMC). Hypothyroidism did not induce any modifications of RXR $\alpha$ expression. The expression of RAR $\alpha$ and RAR $\gamma$ mRNA was significantly reduced in hypothyroid relative to control subjects $(-18 \%$ and $-25 \%$, respectively), even when an increase in the $\mathrm{ROH}$ concentration level was observed in this situation. The reduction in the retinoid nuclear receptors must be drawn nearer to, firstly, the elevation of the plasma $\mathrm{ROH}$ concentration and, secondly, the RBP:TTR ratio, which seemed to indicate a slight vitamin A deficiency in hypothyroidism. Taken together, these data showed that hypothyroidism induces a deregulation of vitamin A metabolism, leading to hypoexpression of the retinoid nuclear receptors, which is detectable in the PBMC, leading us to assume hypofunction of retinoid signalling. Moreover, the RBP:TTR molar ratio was a good indicator of this phenomenon, better than the ROH plasma concentration. Other data have confirmed this observation; indeed, the good correlation between $\mathrm{ROH}$ concentration and the RAR $\gamma$ mRNA amount, as demonstrated in euthyroid subjects, disappeared in hypothyroid subjects.

In conclusion, hypothyroidism induced changes in plasma thyroid hormones and TSH concentrations but also a decreased expression of TR $\beta$ in PBMC. Interestingly, it seems that thyroidectomy-induced hypothyroidism also generates modifications in the cellular bioavailability of retinoic acid, the manifestation of which is, at the nuclear level, the downregulation of some retinoic acid receptors in human PBMC. From this perspective it might be speculated that hypoactivation of retinoid signalling occurs in other tissues of the hypothyroid individual, similarly to our findings in the liver of hypothyroid rats. (Pallet et al. 1994, Coustaut et al. 1996).

Elsewhere, measurement of retinoid and thyroid receptor expression might be a useful tool for the cellular assessment of the impact of thyroid hormones. Further studies conducted in so-called subclinical situations such as hypothyroidism will be useful to determine the true impact of subtle hormone deficiency at the cellular level and the usefulness of these peripheral cellular markers to characterise the hormonal status when classical thyroid hormone measurement displays only minor changes.

\section{Acknowledgements}

The authors wish to thank K. Mayo for English revision and O. Lavialle for statistical analysis. This research was supported by a grant from the Conseil Régional d'Aquitaine. The authors declare that there is no conflict of interest that would prejudice the impartiality of this scientific work.

\section{References}

Almekinder J, Manda W, Soko D, Lan Y, Hoover DR \& Semba RD 2000 Evaluation of plasma retinol-binding protein as a surrogate measure for plasma retinol concentrations. Scandinavian Fournal of Clinical and Laboratory Investigation 60 199-203.

Aranda A \& Pascual A 2001 Nuclear hormone receptors and gene expression. Physiological Review 81 1269-1304.

Bastien J \& Rochette-Egly C 2004 Nuclear retinoid receptors and the transcription of retinoid-target genes. Gene $3281-16$.

Centanni M, Maiani G, Parkes AB, N'Diaye AM, Ferro-Luzzi A \& Lazarus JH 1995 Thyroid homeostasis and retinol circulating complex relationships in a severe iodine-deficient area of Senegal. fournal of Endocrinological Investigation $18608-612$.

Centanni M, Maiani G, Vermiglio F, Canettieri G, Sanna AL, Moretti F, Trimarchi F \& Andreoli M 1998 Combined impairment of nutritional parameters and thyroid homeostasis in mildly iodine-deficient children. Thyroid 8 155-159.

Coustaut M, Pallet V, Garcin H \& Higueret P 1996 The influence of dietary vitamin A on triiodothyronine, retinoic acid, and glucocorticoid receptors in liver of hypothyroid rats. British fournal of Nutrition 76 295-306.

Coya R, Carro E, Mallo F \& Dieguez C 1997 Retinoic acid inhibits in vivo thyroid-stimulating hormone secretion. Life Sciences $\mathbf{6 0}$ 247-250.

de Pee S \& Dary O 2002 Biochemical indicators of vitamin A deficiency: serum retinol and serum retinal binding protein. Journal of Nutrition 132 2895S-2901S.

Duntas LH 2002 Thyroid disease and lipids. Thyroid 12 287-293. 
Efstathiadou Z, Bitsis S, Milionis HJ, Kukuvitis A, Bairaktari ET, Elisaf MS \& Tsatsoulis A 2001 Lipid profile in subclinical hypothyroidism: is L-thyroxine substitution beneficial? European Fournal of Endocrinology 145 705-710.

Enderlin V, Vallortigara J, Alfos S, Féart C, Pallet V \& Higueret P 2004 Retinoic acid reverses the PTU-related decrease of its own receptors and neurogranin level in mice brain. Fournal of Physiology and Biochemistry, $60191-198$.

Giguere V, Ong ES, Segui P \& Evans RM 1987 Identification of a receptor for the morphogen retinoic acid. Nature $\mathbf{3 3 0}$ 624-629.

Goswami UC \& Choudhury S 1999 The status of retinoids in women suffering from hyper- and hypothyroidism: interrelationship between vitamin A, beta-carotene and thyroid hormones. International Fournal for Vitamin and Nutrition Research 69 $132-135$

Gullberg H, Rudling M, Forrest D, Angelin B \& Vennstrom B 2000 Thyroid hormone receptor beta-deficient mice show complete loss of the normal cholesterol 7 alpha-hydroxylase (CYP7A) response to thyroid hormone but display enhanced resistance to dietary cholesterol. Molecular Endocrinology 14 1739-1749.

Haendler B, Hofer-Warbinek R \& Hofer E 1987 Complementary DNA for human T-cell cyclophilin. EMBO fournal 6 947-950.

Heitman B \& Irizarry A 1995 Hypothyroidism: common complaints, perplexing diagnosis. The Nurse Practitioner $2054-60$.

Hercberg S, Preziosi P, Galan P, Devanlay M, Keller H, Bourgeois C, Potier de Courcy G \& Cherouvrier F 1994 Vitamin status of a healthy French population: dietary intakes and biochemical markers. International fournal for Vitamin and Nutrition Research $\mathbf{6 4}$ 220-232.

Higueret P, Pailler I \& Garcin H 1989 Vitamin A deficiency and tri-iodothyronine action at the cellular level in the rat. Fournal of Endocrinology 121 75-79

Husson M, Enderlin V, Alfos S, Féart C, Higueret P \& Pallet V 2003 Triiodothyronine administration reverses vitamin A deficiency-related hypo-expression of retinoic acid and triiodothyronine nuclear receptors and of neurogranin in rat brain. British Fournal of Nutrition 90 191-98.

Ingenbleek Y, Van Den Schrieck HG, De Nayer P \& De Visscher M 1975 Albumin, transferrin and the thyroxine-binding prealbumin/retinol-binding protein (TBPA-RBP) complex in assessment of malnutrition. Clinica Chimica Acta 63 61-67.

Krust A, Kastner P, Petkovich M, Zelent A \& Chambon P 1989 A third human retinoic acid receptor, hRAR-gamma. PNAS 86 $5310-5314$.

Laudet V, Begue A, Henry-Duthoit C, Joubel A, Martin P, Stehelin D \& Saule S 1991 Genomic organization of the human thyroid hormone receptor alpha (c-erbA-1) gene. Nucleic Acids Research 19 $1105-1112$

Leclercq M \& Bourgeay-Causse M 1981 A simple, reliable fast method: simultaneous proportioning of retinol and serum tocopherol by high performance liquid chromatography. Revue Institut Pasteur Lyon 14 475-496.

Li D, Li T, Wang F, Tian H \& Samuels HH 2002 Functional evidence for retinoid $\mathrm{X}$ receptor (RXR) as a nonsilent partner in the thyroid hormone receptor/RXR heterodimer. Molecular and Cellular Biology 22 5782-5792.

Li DQ, Kuang AK, Ding T, Chen JL \& Xu MY 1990 Nuclear 3,5, $3^{\prime}$-triiodothyronine receptors (T3R) of circulating human lymphocytes in hyper- and hypothyroidism and nonthyroidal diseases. Chinese Medical Fournal (England) 103 355-358.

Lomo J, Smeland EB, Ulven S, Natarajan V, Blomhoff R, Gandhi U, Dawson MI \& Blomhoff HK 1998 RAR-, not RXR, ligands inhibit cell activation and prevent apoptosis in B-lymphocytes. Journal of Cellular Physiology 175 68-77.

Macchia PE, Takeuchi Y, Kawai T, Cua K, Gauthier K, Chassande O, Seo H, Hayashi Y, Samarut J, Murata Y, Weiss RE \&
Refetoff S 2001 Increased sensitivity to thyroid hormone in mice with complete deficiency of thyroid hormone receptor alpha. PNAS 98 349-54.

Mangelsdorf DJ \& Evans RM 1995 The RXR heterodimers and orphan receptors. Cell $\mathbf{8 3} 841-850$.

Mangelsdorf DJ, Ong ES, Dyck JA \& Evans RM 1990 Nuclear receptor that identifies a novel retinoic acid response pathway. Nature 345 224-229.

Marill J, Idres N, Capron CC, Nguyen E \& Chabot GG 2003 Retinoic acid metabolism and mechanism of action: a review. Current Drug Metabolism 4 1-10.

Marrocco W, Adoncecchi L, Suraci C, Pecora P, Porra R, Gallinella B \& Cavina G 1984 Behavior of vitamin A, beta-carotene, retinol binding protein and préalbumine in the plasma of hypo- and hyperthyroid subjects. Bolletino della Societa Italiana di Biologia Sperimentale $60769-775$.

Meier-Heusler S, Pernin A, Liang H, Goumaz MO, Burger AG \& Meier CA 1995 Quantitation of beta 1 triiodothyronine receptor mRNA in human tissues by competitive reverse transcription polymerase chain reaction. Fournal of Endocrinological Investigation 18 767-773.

Nagayama Y, Yamashita S, Hirayu H, Ashizawa K, Harakawa S, Inoue S, Izumi M \& Nagataki S 1988 Expression and regulation of c-erb-A mRNA from lymphocytes in patients with thyroid dysfunction. Endocrinologia Faponica 35 463-467.

Oppenheimer JH 1999 Evolving concepts of thyroid hormone action. Biochimie 81 539-543.

Pallet V, Audouin-Chevallier I, Verret C, Garcin H \& Higueret P 1994 Retinoic acid differentially modulates triiodothyronine and retinoic acid receptors in rat liver according to thyroid status. European Fournal of Endocrinology 131 377-384.

Raich N, Romeo PH, Dubart A, Beaupain D, Cohen-Solal M \& Goossens M 1986 Molecular cloning and complete primary sequence of human erythrocyte porphobilinogen deaminase. Nucleic Acids Research 14 955-968.

Robbins J 2002 Transthyretin from discovery to now. Clinical Chemistry and Laboratory Medicine 40 1183-1190.

Rosales FJ, Chau KK, Haskell MH \& Shankar AH 2002 Determination of a cut-off value for the molar ratio of retinol-binding protein to transthyretin (RBP:TTR) in Bangladeshi patients with low hepatic vitamin A stores. Fournal of Nutrition 132 3687-3692.

Rovet J \& Daneman D 2003 Congenital hypothyroidism: a review of current diagnostic and treatment practices in relation to neuropsychologic outcome. Paediatric Drugs 5 141-149.

Schräder M \& Carlberg C 1994 Thyroid hormone and retinoic acid receptors form heterodimers with retinoid $\mathrm{X}$ receptors on direct repeats, palindromes, and inverted palindromes. DNA and Cell Biology 13 333-341.

Sporn MB, Roberts, AB \& Goodman D 1994 The Retinoids: Biology, Chemistry, and Medicine. $2^{\text {nd }}$ Edn. Raven Press: New York.

Stockigt JR 2002 Case finding and screening strategies for thyroid dysfunction. Clinica Chimica Acta 315 111-124.

Surks MI, Ortiz E, Daniels GH, Sawin CT, Col NF, Cobin RH, Franklyn JA, Hershman JM, Burman KD, Denke MA, Gorman C, Cooper RS \& Weissman NJ 2004 Subclinical thyroid disease: scientific review and guidelines for diagnosis and management. Fournal of the American Medical Association 291 228-238.

Szabova L, Macejova D, Dvorcakova M, Mostbock S, Blazickova S, Zorad S, Walrand S, Cardinault N, Vasson MP, Rock E \& Brtko J 2003 Expression of nuclear retinoic acid receptor in peripheral blood mononuclear cells (PBMC) of healthy subjects. Life Sciences 72 831-836.

van Bennekum AM, Wei S, Gamble MV, Vogel S, Piantedosi R, Gottesman M, Episkopou V \& Blaner WS 2001 Biochemical basis for depressed serum retinol levels in transthyretin-deficient mice. Fournal of Biological Chemistry 276 1107-1113. 
Viguerie N \& Langin D 2003 Effect of thyroid hormone on gene expression. Current Opinion in Clinical Nutrition and Metabolism Care 6 $377-381$.

Weinberger C, Thompson CG, Ong ES, Lebo R, Gruol DJ \& Evans RM 1986 The c-erb-A gene encodes a thyroid hormone. Nature 324 641-646.

Yen PM 2001 Physiological and molecular basis of thyroid hormone action. Physiological Review 81 1097-1142.
Zago LB, Dupraz H, Sarchi MI \& Rio ME 2002 The molar ratio of retinol-binding protein to transthyretin in the assessment of vitamin A status in adults. Proposal of a cut-off point. Clinical Chemistry and Laboratory Medecine 40 1301-1307.

Received 15 December 2004

Accepted 27 January 2005 